\title{
Alternative Measures to Reduce Carbon Dioxide Emissions in the Republic of Cuba
}

\author{
Daniel D. Guerra', Emiliia V. lakovleva ${ }^{1 *}$, Andrey Y. Shklyarskiy ${ }^{1}$ \\ 1 Department of General Electrical Engineering, Saint-Petersburg Mining University, 2, 21-st Line, Vasilyevsky \\ Island, 199106, St. Petersburg, Russian Federation. \\ “Corresponding author's e-mail: em88mi@gmail.com
}

\begin{abstract}
In this paper, one of the ways to reduce carbon dioxide $\left(\mathrm{CO}_{2}\right)$ emissions into the atmosphere through the use of various types of solar power plants (SES) was considered. The paper provides an overview of the energy resources that currently exist in the Republic of Cuba, as well as the new investments made by the country in order to introduce a more extensive use of the renewable energy sources. The paper also describes the benefits of renewable energy that help to reduce the $\mathrm{CO}_{2}$ emissions into the environment.
\end{abstract}

Keywords: carbon dioxide, renewable energy sources, Republic of Cuba, solar plant

\section{INTRODUCTION}

$\mathrm{CO}_{2}$ emission in the air has grown rapidly since the measurements began almost 60 years ago, increasing from 316 parts per million ( $\mathrm{ppm}$, the number of units of one substance per million units) in 1958 to more than $400 \mathrm{ppm}$ today. At the moment, the data for the previous year are not available, but the latest data for 2016 confirm an annual record trend: when $403.3 \mathrm{ppm}$ is reached, the amount of carbon dioxide $\left(\mathrm{CO}_{2}\right)$ in the atmosphere has reached the highest level in the last 800000 years. This is the second year in a row that goes beyond the turning point, which exceeded $400 \mathrm{ppm}$ in 2015, when at the beginning of the industrial revolution it was $278 \mathrm{ppm}$ (Zmami and Salhaб,2020).

According to the data obtained by the National Oceanic and Atmospheric Administration EE. UU (NOAA), the gas level growth has not declined in the recent decades. It has been established that a safe level of carbon dioxide in the atmosphere is $350 \mathrm{ppm}$. The consequences of exceeding this level are devastating storms and tsunamis, droughts, forest fires. Over the past year, fires took place on the territory of Russia, which led to disastrous consequences - several million hectares of forest burned out, thousands of different species of animals died, and damage was caused to the population. Massive fires in Australia continue from 2019 to now, which has led to the deaths of more than 1 million animals, according to estimates. It should be noted that during the forest fires, an enormous amount of carbon dioxide is also emitted into the atmosphere, while the burning out of forests leads to a decrease in the cover that can absorb the $\mathrm{CO}_{2}$ from the atmosphere. Therefore, reducing the industrial $\mathrm{CO}_{2}$ emissions into the atmosphere is an extremely urgent task.

There are many factors that contribute to the carbon dioxide emissions into the atmosphere the gas emissions produced by the public or private transport, the gas emissions from the electricity production using the non-renewable energy sources, the natural gas emissions from the environment and many others.

Therefore, the technological processes of the last years of this decade and the last decade have been focused on the development of technologies in all areas in order to increase the efficiency of industrial processes, including agriculture, electricity production, transport, among other things (Abramovich, 2018). 
An example of the technological advances in the electricity generation sector is the use of the renewable energy sources (Kirsanova et all, 2018). Various technologies for the use of solar energy in this area have been developed around the world, including the solar modules from various materials with greater efficiency in collecting solar energy, solar tracking systems, solar thermal systems, as well as developing various components of these systems. For example, during the period of the photovoltaic modules development, the efficiency of the solar panel was $16-17 \%$, while today the panels with an efficiency of $20-23 \%$ are widely available. In addition, there are single samples with an efficiency reaching $50 \%$.

\section{The electrical potential of the Republic of Cuba}

There are currently 10 factories in Cuba (Table 1) that have power plants for generating electricity with a total installed electric capacity of $2.5 \mathrm{GW}$. About half of all the energy facilities in Cuba were built with the full or partial assistance of the USSR, and subsequently Russia. In addition to 10 thermoelectric power plants, there were 1,405 generator sets in the country until 2017 (855 diesel groups and 550 Fuel groups).

\section{Installed capacity of renewable energy in the Republic of Cuba.}

In accordance with the policies adopted by the Government of the Republic of Cuba, namely, the government commission for the development of the renewable energy policies for the period 2010-2030, it is planned to put into operation the power plants based on the renewable energy sources with an installed capacity of 2269 MW. Bulding the bioelectric power plants with a capacity of $755 \mathrm{MW}$, direct conversion solar power plants with a capacity of $700 \mathrm{MW}$ (Figure 1), wind power generators with a total capacity of $633 \mathrm{MW}$ is planned, in addition to increasing the installed capacity of the existing small hydropower plants by $56 \mathrm{MW}$.

Today, the Republic of Cuba is looking for the alternatives to fossil fuels, using the renewable energy sources. Recently, in the Republic of Cuba in 16 provinces, the design and construction of 65 solar power plants (capacity of $159.3 \mathrm{MW}$ ) was carried out. At the expense of the state investments, it is planned to build 15 solar power plants (capacity $42 \mathrm{MW}$ ); 9164 isolated solar panels were installed (schools, clinics, etc.)

The Republic of Cuba has a national industry; the Ernesto Che Guevara Electronic Component Manufacturing Company of Pinar del Rio produces the photovoltaic panels with an annual output of $15 \mathrm{MW}$ to service the panel assembly program. In addition, photovoltaic pumping systems, solar chargers, lighting systems and other household equipment that uses the panel as an energy source, is produced.

The installed capacity of the solar power plants today is $21.8 \%$ of the planned $700 \mathrm{MW}$ by 2030. (Table 2). Today, there are four wind farms with a capacity of $11.5 \mathrm{MW}$ in the country (Figure 2). Two wind farms with a total capacity of $102 \mathrm{MW}$ are being built north of the Las Tunas province (Table 2) (Pedraza, 2018).

There is a wind map of Cuba which reflects that the wind resource is located mainly in the north-eastern and central parts of the country. The technical potential is assumed to exceed $1100 \mathrm{MW}$, taking into account the use of $1.5 \mathrm{MW}$ wind turbines, backed by the International Consulting Garrad Hassan \& Partners guarantee (Garrad Hassan Iranian branch).

Table 1. A thermoelectric power station that operates in the Cuban Republic

\begin{tabular}{|l|l|c|c|c|c|}
\hline $\mathrm{N}$ & Thermoelectric Power Station & provinces & Installed Power (MW) & In use (MW) & $\begin{array}{c}\text { open } \\
\text { year }\end{array}$ \\
\hline 1 & Mariel & Artemisa & 600 & 300 & 1982 \\
\hline 2 & Antonio Maceo & Habana & 64 & 64 & 1971 \\
\hline 3 & Santa Cruz & Mayabeque & 300 & $300+164^{*}$ & 1991 \\
\hline 4 & Antonio Guiteras & Matanzas & 330 & 300 & 1988 \\
\hline 5 & Carlos Manuel de Céspedes & Cienfuegos & 338 & 158 & 1979 \\
\hline 6 & 10 de Octubre & Camagüey & 360 & 360 & 1978 \\
\hline 7 & Lidio Ramón Pérez, de Faltón & Holguín & 500 & 500 & 1988 \\
\hline 8 & Antonio Maceo (Renté) & $\begin{array}{c}\text { Santiago de } \\
\text { Cuba }\end{array}$ & 500 & 400 & 1967 \\
\hline *4 blocks with 35 MW gas turbines & \multicolumn{2}{|l}{} \\
\hline
\end{tabular}




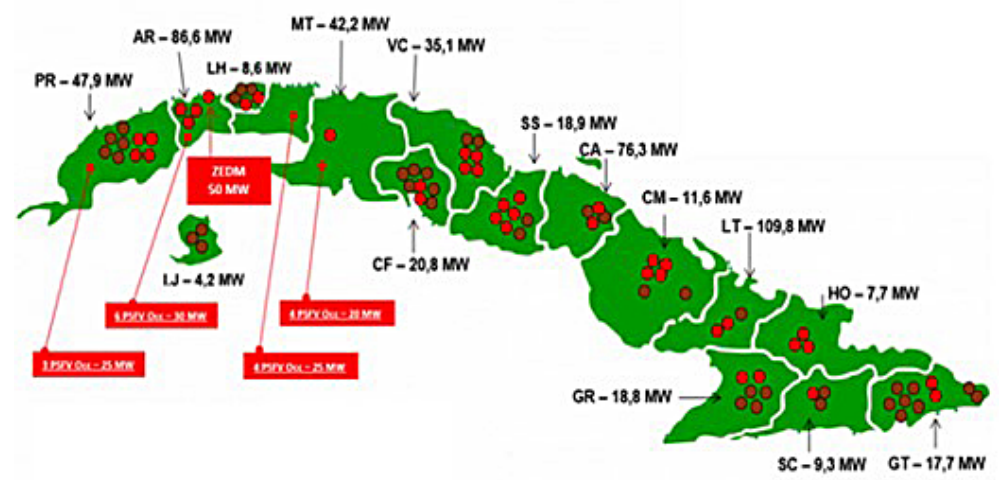

Figure 1. Photovoltaic power plants installed on the territory of the Republic of Cuba. (The red dots arethe solar power plants under construction and the brown dots are the solar power plants commissioned in 2020) (Pedraza, 2018).

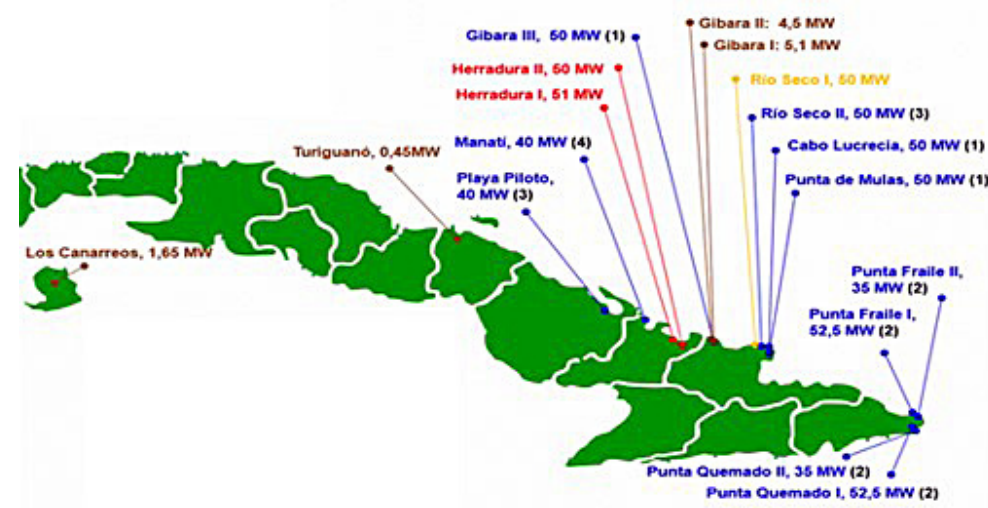

Figure 2. Wind farms installed in the Republic of Cuba. (The red dots are the wind farms under construction, the brown dots are the wind farms in operation in 2020 and the blue dots are the wind farms being negotiated) (Pedraza, 2018).

The country has 162 hydroelectric power stations with a total installed capacity of $71.9 \mathrm{MW}$, which generated $83 \mathrm{GWh}$ in 2017 , of which 34 are connected to the SEN, and 128 provide isolated services to 8,486 houses and 416 economic and social goals. The the Hanabanilla hydroelectric station with an installed capacity of $43 \mathrm{MW}$ has the highest output (Table 2).

There are currently 57 sugar factories with a potential of 16 million tons of cane that will be ground during each harvesting period. In order to supply electricity to the sugar industry, 469.2 MW plants were installed (Figure 4 and Table 2).

The sugar industry provides for the production of medium and high pressure steam boilers at the Jesus Menendes factory in the municipality of Sagua la Grande, in the province of Villa Clara, to support the program of 19 bioelectric plants for the production of sugarcane biomass and the development of a forest biomass power plant, and also the production of components and assemblies to enhance the integration of the bioelectric installations.

There are 6 areas of great deep sea that surround the island. The differences in the sea temperatures with the OTET technology have obvious uses. The bays from north to east coast have important potential due to the sea currents.

Figure 5 shows the behavior of the country's energy matrix in the period from 2000 to 2016. From the graph, it follows that the introduction of the power plants based on the renewable energy resources in the country is successful. According to the new government policy, an increase in the use of renewable energy sources for electricity production by $24 \%$ is expected by 2030 .

\section{The introduction of more effective technologies for capturing sunlight}

On the territory of the Republic of Cuba, the solar power plants occupy the second place in the introduction and future generation of energy 


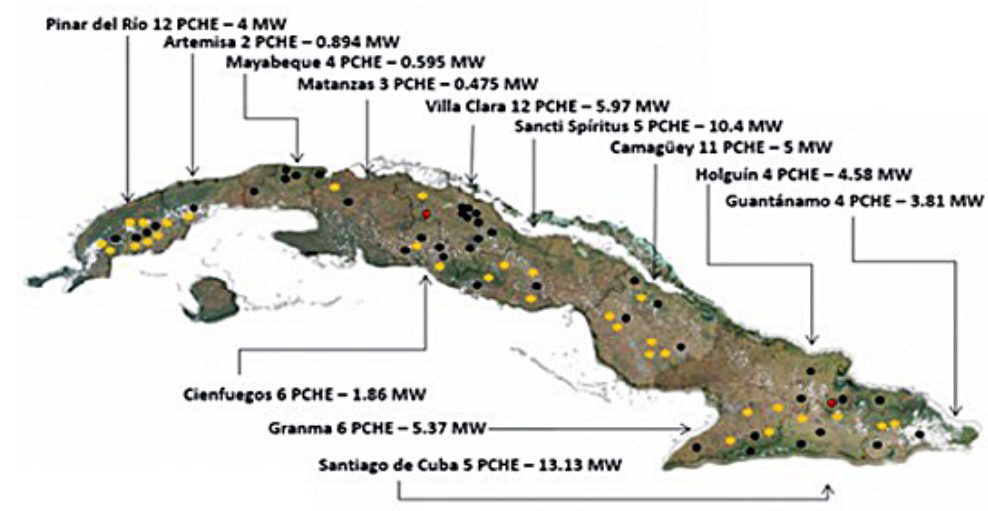

Figure 3. Hydroelectric power plants installed in the Republic of Cuba. (The red dots are the hydropower plants under construction, and the black dots are the hydropower plants that may be built in the future) (Pedraza, 2018).

(table 2). This is due to a number of advantages that solar power plants have, which include:

- Solving the problems of the electricity supply in the absence of network energy sources, independence from the centralized energy sources, utility infrastructure.

- Removing the restrictions on allocated capacities.

- Energy saving.

- Conservation of territories and natural resources from laying power lines.

- Economic expediency.

- Environmental policy and environmental safety.

Today, there are two types of SES, different in the principle of generating electric energy - SES direct conversion, which use photovoltaic modules, and SES two-stage conversion. Such SES include tower and plate SES, solar concentrators. The principle of operation of such SES is based on heating the heat carrier parameters suitable for use in a turbogenerator (Alvarez, 2014).
The principle of the photoelectric SES operation is based on the direct conversion of the solar energy into the electrical energy based on the photoelectric effect (Alvarez, 2014). The classic and most common type of the SES for a direct conversion of the solar energy into the electrical energy is a stationary SES. The photovoltaic modules included in serial and parallel groups are installed at an angle equal to the geographical latitude of the area, and are oriented to the southern hemisphere.

Currently, all solar power plants operating in the Republic of Cuba have stationary solar generators and import electrical components such as inverters, regulators and transformers. However, the solar modules are assembled using the Chinese technology in the province of Pinar del Rio, Republic of Cuba.

The current technology for tracking the Sun and positioning the solar module on the brightest object is not currently used in the solar power generation systems in the Republic of Cuba. This fact is one of the main economic and technical topics of the studies currently being conducted

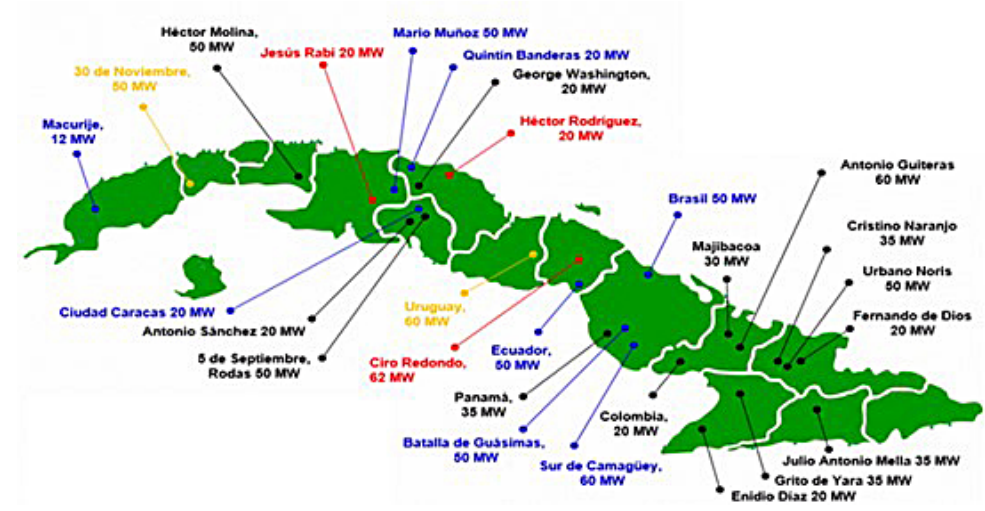

Figure 4. Biomass power plants installed in the Republic of Cuba. (The red dots are the built plants, and the black ones are being negotiatedand designed) (Pedraza, 2018). 
Table 2. Summary of Renewable Energy Generated in Cuba

\begin{tabular}{|l|c|c|c|}
\hline \multicolumn{1}{|c|}{ Renewableenergy } & Designcapacityuntil 2030 & Built-in and in operation & Performance (\%) \\
\hline Bioelectricpowerstations & $755 \mathrm{MWt}$ & $469,2 \mathrm{MWt}$ & $62 \%$ \\
\hline Photovoltaicstations & $700 \mathrm{MWt}$ & $159 \mathrm{MWt}$ & $22 \%$ \\
\hline Windpowerinstallations & $633 \mathrm{MWt}$ & $11,5 \mathrm{MWt}$ & $18 \%$ \\
\hline Small hydropowerplants & $133 \mathrm{MWt}$ & $68.3 \mathrm{MWt}$ & $51 \%$ \\
\hline Total & $2221 \mathrm{MWt}$ & $708 \mathrm{MWt}$ & $32 \%$ \\
\hline
\end{tabular}

in the country to evaluate this technology taking into account the climatic conditions of the region.

From the point of view of the environmental assessment of these solar systems operating in the Republic of Cuba, it can be argued that such solutions represent an environmentally friendly alternative way of generating the electrical energy.

The environmental and economic impact of these power generation systems can be estimated using several indicators, one of which is the $\mathrm{CO}_{2}$ emissions, since for every $1 \mathrm{kWh}$ of electricity generated from renewable sources, $1 \mathrm{kWh}$ is no longer generated from the non-renewable energy sources.

As an example of the above, it can be said that at a solar power plant with an installed capacity of 2.5 MW in the province of Santiago de Cuba, which currently produces $3.6 \mathrm{GWh}$ of energy per year, $3.7 \mathrm{kt} \mathrm{CO}_{2} / \mathrm{kWh}$ is no longer emitted into the atmosphere.

Using the following equation 1 (Alvarez et al., 2014), it is possible to theoretically calculate the decrease in the carbon dioxide concentration in the atmosphere if the concept of electricity production using the renewable resources such as solar and wind energy, biomass energy and other types of energy is applied.

$$
E=(F E * E A) * 10^{-} 6
$$

Where: $E-\mathrm{CO}_{2}$ emissions (ct $\mathrm{CO} 2 / \mathrm{kWh}$ ), $F E-$ Emission factor $\left(\mathrm{g} \mathrm{CO}_{2} / \mathrm{kWh}\right)$, $E A$ - Electricity saved ( $\mathrm{kW} /$ year).
In the recent studies conducted in the Republic of Cuba under the specific climatic conditions of the region, more efficient technologies can be used to capture the sunlight (for example, a solar tracking system), which can increase the values by $25-30 \%$ of the electricity supplied to the national power grid, which will mean a reduction of the $\mathrm{CO}_{2}$ emissions of 4.7 ct $\mathrm{CO}_{2} / \mathrm{kWh}$ (Using Equation 1 with an emission factor of $\left.1050 \mathrm{~g} \mathrm{CO}_{2} / \mathrm{kWh}\right)$.

\section{$\mathrm{CO}_{2}$ emissions from electricity production in the Republic of Cuba}

According to the Carbon Dioxide Information Analysis Center, Environmental Sciences Division of the Oak Ridge National Laboratory (Oak Ridge National Laboratory), The $\mathrm{CO}_{2}$ emissions generated by the Republic of Cuba between 1960-2014 averaged $26.5876 \mathrm{kt}$.

Figure 7 shows the behavior of carbon dioxide in the atmosphere that was released between 1960 and 2014, where it is obvious that the reduction in $\mathrm{CO}_{2}$ that occurred from 1991 to 2008 was mainly due to the economic crisis faced by the Republic of Cuba at that time. After this critical period, the $\mathrm{CO}_{2}$ emissions reached their maximum value of $38,375 \mathrm{kt}$. In 2010, they decreased again in subsequent years due to an increase in the use of the renewable energy sources in the country for electricity generation (CDIAC).

Energy matrix of the Republic of Cuba

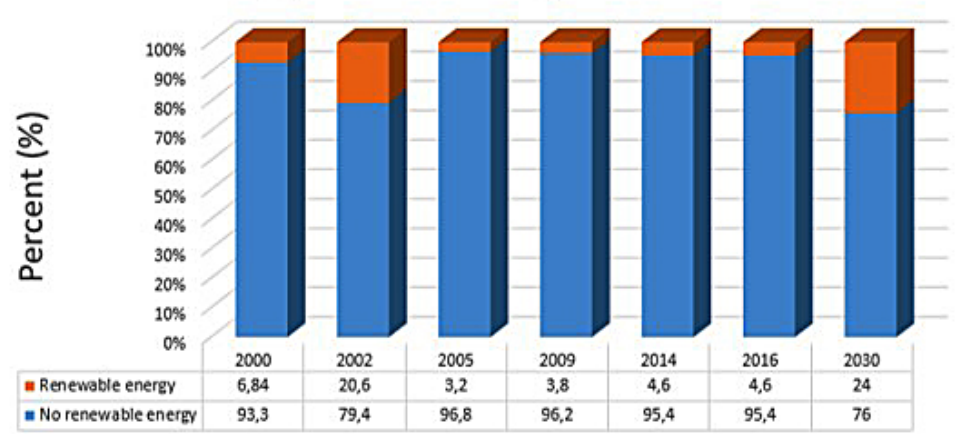

Figure 5. The energy matrix of the Republic of Cuba 


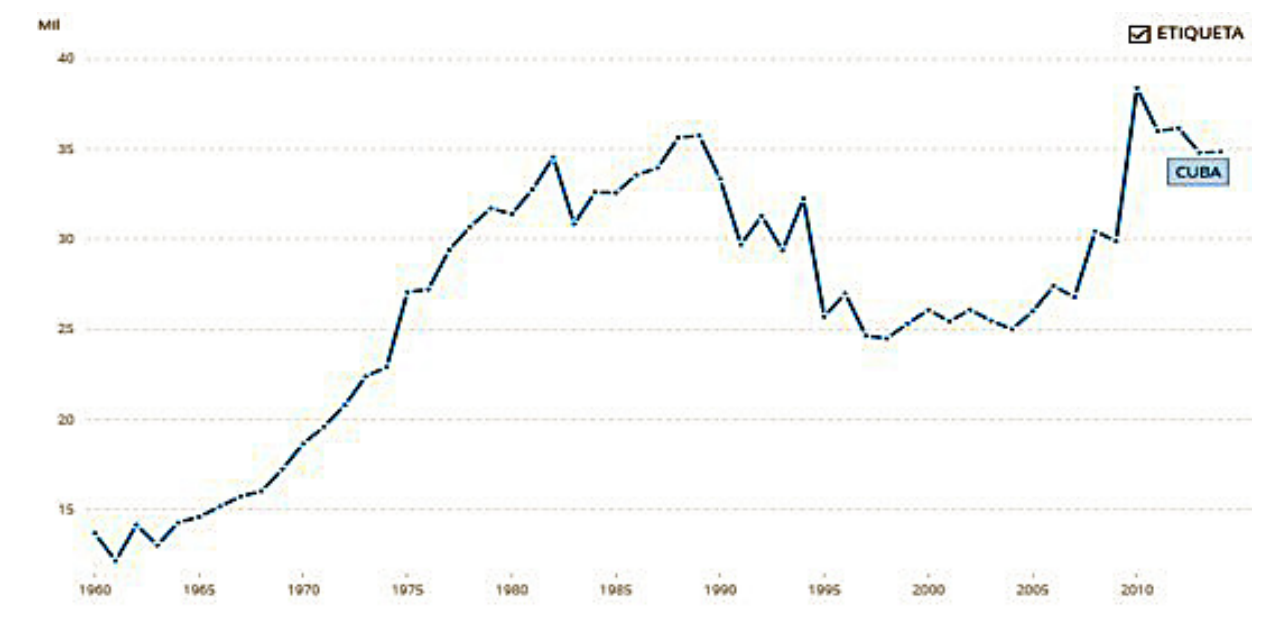

Figure 6. $\mathrm{CO}_{2}$ emissions emitted into the atmosphere by the Republic of Cuba (1960-2014)

According to the studies conducted by the Ministry of Energy and Mining (MINVAS) of the Republic of Cuba in 2018, the average $\mathrm{CO}_{2}$ emission factor corresponding to the production of electricity from the non-renewable energy sources was $1,050 \mathrm{~g} / \mathrm{kWh}$. It is assumed that by 2030 this emission factor will be reduced to $993 \mathrm{~g} / \mathrm{kWh}$ (Donat et al., 2014).

\section{CONCLUSION}

According to the study, itcan be concluded that the policy applied by the Republic of Cuba is successful, since the country's energy matrix is being developed with the aim of increasing its efficiency and reducing the environmental pollution through the use of renewable energy sources for generating electricity. In addition, it has been noted that the $\mathrm{CO}_{2}$ emission trend has been decreasing since 2010, which is favorable for achieving a clean environment.

On the other hand, it can be argued that the use of the solar tracking systems can further reduce the $\mathrm{CO}_{2}$ emissions into the atmosphere, which is a positive aspect for this type of technology.

\section{REFERENCES}

1. Abramovich, B.N. (2018) Journal of Mining Institute, 229, pp. 31-41.

2. Alvarez M., Cuello N., Berigüete R. (2014) Determination of the Grid CO2 Emission Factor for the Electrical System of the Dominican Republic. Proceeding of the 19th International Symposium on
Energy \& Technology Innovation Forum, Puerto Rico Energy Center-Laccei, February 20-21, 2014, Puerto Rico, pp. 1-10

3. Carbon Dioxide Information Analysis Center, Environmental Sciences Division, Oak Ridge National Laboratory, Tennessee, United States, viewed 5 January 2020, https://www.indexmundi.com/facts/ cuba/co2-emissions\#EN.ATM.CO2E.KT

4. Donat L., Velten E.K, Prahl A., Duwe M., Zane E.B (2014) Assessment of climate change policies in the context of the European Semester, Ecologic Institute - eclareon, 2014, pp. 1-18

5. Fuente: Carbon Dioxide Information Analysis Centre (CDIAC), viewed 15 January 2020, https://elordenmundial.com/mapas/ paises-emisiones-co2-1751-2016/

6. Kirsanova, N.Y., Lenkovets, O.M., Nikulina, A.Y. Renewable energy sources (RES) as a factor determining the social and economic development of the arctic zone of the Russian Federation. Proceeding of the 18th International Multidisciplinary Scientific GeoConference Surveying Geology and Mining Ecology Management, SGEM. Albena, Bulgaria: SGEM International Scientific GeoConference, T 18, 2018. pp. 679-686.

7. Six Decades of Carbon Dioxide Concentration in the Atmosphere, National Oceanic \& Atmospheric Adm. (NOAA), viewed 5 January 2020, https:// www.noaa.gov/news/global-carbon-dioxidegrowth-in-2018-reached-4th-highest-on-record

8. Pedraza J.M. (2018). Focus on Renewable Energy Source, pp. 1-59.

9. Zmami M. \& Salha O.B. (2020) An empirical analysis of the determinants of $\mathrm{CO} 2$ emissions in GCC countries. The International Journal of Sustainable Development and World Ecology. DOI: 10.1080/13504509.2020.1715508 